\title{
HIGH DOSES OF CARBAMAZEPINE FOR REFRACTORY PARTIAL EPILEPSY
}

\author{
CRISTIANA BORGES PEREIRA, CARLOS OTTO HEISE, ARTHUR CUKIERT
}

\begin{abstract}
Forty-eight patients with partial seizures were analysed during treatment with $1200 \mathrm{mg} / \mathrm{d}$ or more of carbamazepine (CBZ). Thirty-three were on monotherapy and fifteen on polytherapy. The other drugs were kept unchanged in the patients on polytherapy. The dose of $\mathrm{CBZ}$ was increased if no control was observed and the patient had no side effects. The doses used ranged between 1200 and $1900 \mathrm{mg} /$ day $(1200 \mathrm{mg} /$ day, $\mathrm{n}=18$; $1300 \mathrm{mg} /$ day, $n=1 ; 1400 \mathrm{mg} /$ day, $\mathrm{n}=7 ; 1600 \mathrm{mg} /$ day, $\mathrm{n}=9 ; 1700 \mathrm{mg} /$ day, $\mathrm{n}=4 ; 1800 \mathrm{mg} /$ day, $\mathrm{n}=8 ; 1900 \mathrm{mg} /$ day, $n=1$ ). Anticonvulsant plasma levels were taken to confirm patient compliance. The average plasma level was $9.6 \mathrm{ug} / \mathrm{mL}$. The period of follow up varied from 3 to 96 months $(M=25.6)$. Seizure's control was observed in 7 (14.48\%) patients taking $1200 \mathrm{mg} /$ day and in $2(4.16 \%)$ patients taking $1400 \mathrm{mg} /$ day of CBZ. Thirty-nine patients did not show any control $(81.21 \%)$. Ten patients $(20.81 \%)$ had signs of intoxication. When patients have no improvement with $1400 \mathrm{mg} /$ day, it is difficult to obtain any control despite the use , f higher doses of $\mathrm{CBZ}$, which frequently expose the patient to significant side effects.
\end{abstract}

KEY-WORDS: epilepsy, carbamazepine, effectiveness, side effects.

\section{Altas doses de carbamazepina para epilepsia parcial refratária}

RESUMO - Foram analisados 48 pacientes epilépticos com crises parciais que faziam uso de carbamazepina (CBZ) em doses iguais ou superiores a $1200 \mathrm{mg}$ por dia. Trinta e três estavam em monoterapia e 15 em politerapia. As outras medicaçōes foram mantidas constantes durante a manipulação da dose de CBZ nos pacientes em politerapia. $O$ critério utilizado para o aumento da dose de $\mathrm{CBZ}$ foi a falta de controle clínico e a ausência de efeitos colaterais (independente da dosagem sérica). A dose máxima variou de 1200 a $1900 \mathrm{mg} / \mathrm{dia}(1200 \mathrm{mg}$, $\mathrm{n}=18 ; 1300 \mathrm{mg} / \mathrm{dia}, \mathrm{n}=1 ; 1400 \mathrm{mg} / \mathrm{dia}, \mathrm{n}=7 ; 1600 \mathrm{mg} / \mathrm{dia}, \mathrm{n}=9 ; 1700 \mathrm{mg} / \mathrm{dia}, \mathrm{n}=4 ; 1800 \mathrm{mg} / \mathrm{dia}, \mathrm{n}=8 ; 1900$ $\mathrm{mg} / \mathrm{dia}, \mathrm{n}=1$ ). Dosagens séricas de anticonvulsivantes eram utilizadas no sentido de confirmar a aderência ao tratamento. A média das dosagens disponiveis foi de $9,6 \mathrm{ug} / \mathrm{mL}$. O tempo de seguimento variou de 3 a 96 meses $(M=25,6)$. Houve controle das crises em $7(14,48 \%)$ pacientes com $1200 \mathrm{mg} / \mathrm{dia}$ e em $2(4,16 \%)$ pacientes com $1400 \mathrm{mg} / \mathrm{dia}$. Trinta e nove pacientes näo obtiveram controle $(81,21 \%)$. Dez pacientes $(20,81 \%)$ mostraram sinais de intoxicação. Quando doses de $\mathrm{CBZ}$ até $1400 \mathrm{mg}$ não são eficazes, doses mais altas da droga são frequentemente incapazes de controlar as crises epilépticas. Nesta situaçāo, a chance de intoxicação aumenta significativamente sem que haja beneficios para o paciente.

PALAVRAS-CHAVES: epilepsia, carbamazepina, efeitos colaterais, eficácia.

Carbamazepine (CBZ) was introduced in the clinical practice in 1963 and since then several studies demonstrated its efficacy in the treatment of epileptic patients with parcial ${ }^{2}$ and secondarily generalized tonic-clonic seizures ${ }^{3,13,17,22,23}$. It is considered a first line drug in the treatment of such seizures with few side effects ${ }^{16}$. At least $50 \%$ reduction in the frequency of seizures is observed in $75 \%$ of the patients treated with $\mathrm{CBZ}^{7,13}$. Approximately $20-30 \%$ of the patients with focal epilepsy do not get any significant reduction of the seizure's frequency in spite of the adequate treatment with several antiepileptic drugs prescribed on mono or polytherapy, being therefore considered refractory ${ }^{6 .}$

Department of Neurology and Neurosurgery of the University of São Paulo School of Medicine. Aceite: 9-outubro-1995.

Dr. Arthur Cukiert - Rua Nova York 744 apto 131 - 04560-001 São Paulo SP - Brasil. 
$11,16,18$. Treatment is considered a failure when seizures remain severe or there is no reduction in its frequency, despite daily dosages that lead to unacceptable side effects ${ }^{17}$.

The minimum dose of CBZ used in adults is around $600 \mathrm{mg} /$ day and the maximum dose is usually no higher than $1200 \mathrm{mg} /$ day $^{11,22,24}$. In the present study, we analysed the response of refractory patients with partial epilepsy to high doses of CBZ.

\section{METHODS}

Forty-eight patients $(m e n=28$; women $=20$ ) were analysed retrospectively. The inclusion criteria were as follows:

1) simple or complex partial seizures secondarily generalized or not;

2) minimum dose of CBZ of $1200 \mathrm{mg} /$ day;

3) lack of control with doses lower than $1200 \mathrm{mg} /$ day;

4) good compliance.

These patients were selected from a pool of 1500 consecutive cases from the same outpatient clinic at our University Hospital. Age ranged from 18 to 51 years. Mean duration of the epilepsy syndrome was 4.7 years. None of them was diagnosed as having idiophatic epilepsy.

The patients had simple partial seizures $(n=6)$, complex partial seizures $(n=18)$, or simple partial followed by complex partial seizures $(n=24)$. Forty-two patients had secondarily generalized tonic-clonic seizures. Thirtythree were on monotherapy and fifteen on polytherapy. The patients on polytherapy used phenobarbital $(n=7)$, primidone $(n=2)$, phenytoin $(n=1)$, phenobarbital and phenytoin $(n=2)$, primidone and phenytoin $(n=2)$, and clonazepam $(n=1)$. The doses of $\mathrm{CBZ}$ were progressively increased if there was no seizure control and the patient did not show side effects. Determination of anticonvulsant plasma levels was obtained in 25 patients.

\section{RESULTS}

The follow up time ranged from 3 to 96 months (average $=25.6$ months). The maximum dose administered ranged from $1200 \mathrm{mg} /$ day to $1900 \mathrm{mg} /$ day $(1200 \mathrm{mg} /$ day, $n=18 ; 1300 \mathrm{mg} /$ day, $n=1$; $1400 \mathrm{mg} /$ day, $\mathrm{n}=7 ; 1600 \mathrm{mg} /$ day, $\mathrm{n}=9 ; 1700 \mathrm{mg} /$ day, $\mathrm{n}=4 ; 1800 \mathrm{mg} /$ day, $\mathrm{n}=8 ; 1900 \mathrm{mg} /$ day, $\mathrm{n}=1$ ) (Fig 1). Total control of seizures was observed in 7 patients (14.5\%) using $1200 \mathrm{mg} / \mathrm{day}$, and on 2 patients (4.2\%) using $1400 \mathrm{mg} /$ day (Fig 2). Three of these 9 patients were in polytherapy: one was

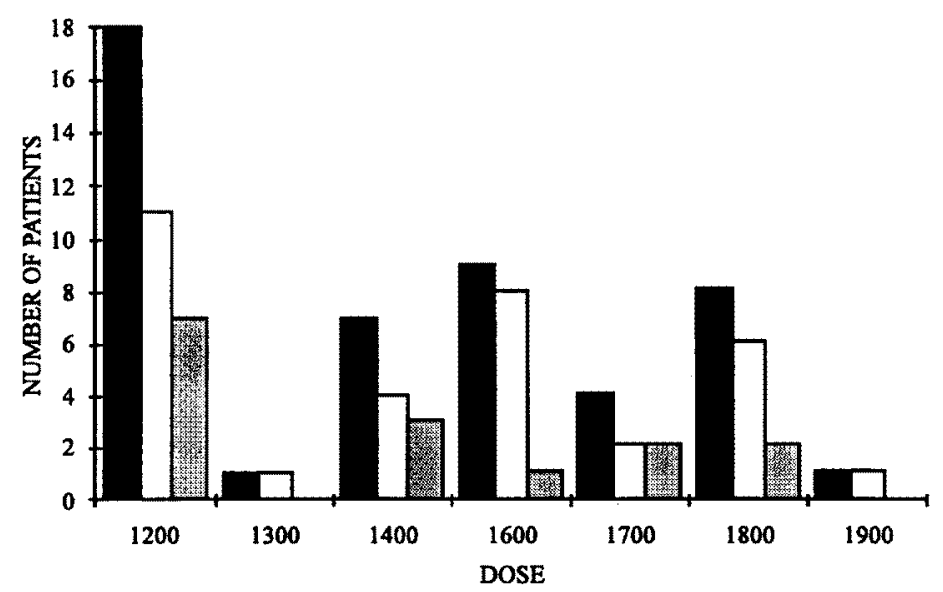

Fig 1. Distribution of the maximum dose of $C B Z$ administred. 


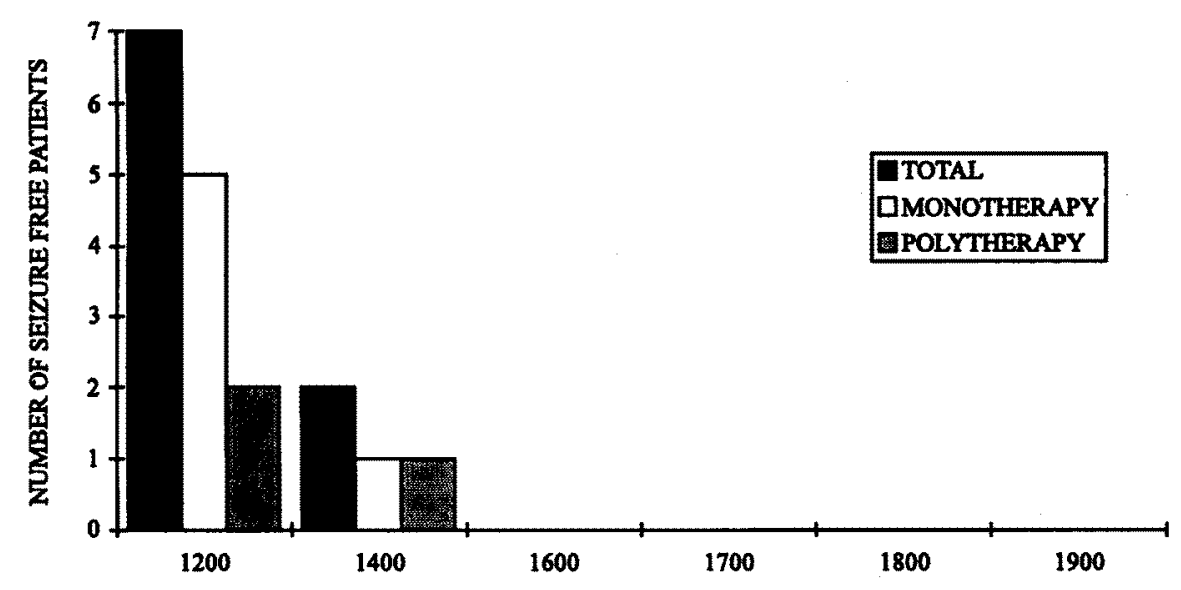

Fig 2. Distribution of seizure free patients in mono and polytherapy.

receiving phenobarbital $50 \mathrm{mg} /$ day and phenytoin $600 \mathrm{mg} /$ day, and two were under phenobarbital $100 \mathrm{mg} /$ day. Thirty-nine patients $(81.2 \%$ ) had no clinical improvement regardless of ihe progressive increase on the dose of $\mathrm{CBZ}$.

Antiepileptic drug monitoring showed plasma levels that varied from 6.0 to $17.0 \mathrm{microg} / \mathrm{mL}$ ( mean: $9.6 \mathrm{microg} / \mathrm{mL}$; therapeutical range: $4.0-10.0 \mathrm{microg} / \mathrm{mL}$ ) (Fig 3). Ten patients showed signs of intoxication: diplopia $(n=6)$, blurred vision $(n=1)$, dizziness $(n=1)$, tremor $(n=1)$, diarrhea $(n=1)$ and vomits $(n=1)$. CBZ dosages were reduced after the appearance of side effects. In 3 cases another drug was introduced and in 3 cases surgery was carried out.

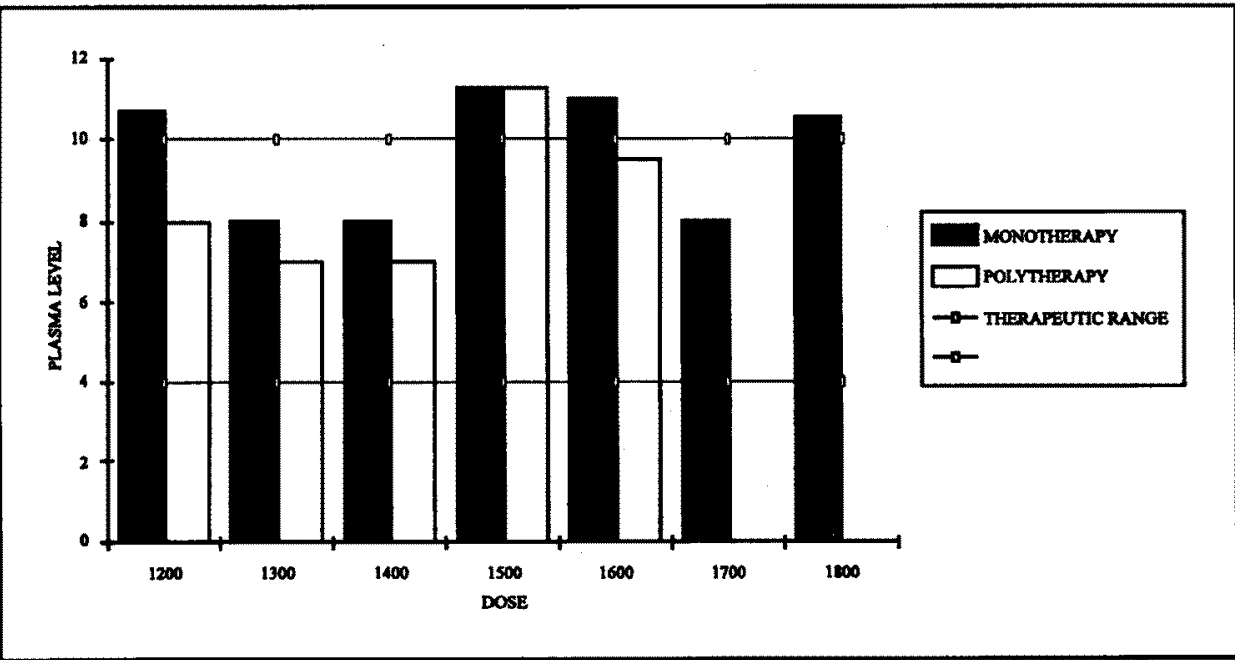

Fig 3. Average plasma levels of $C B Z$ according to the prescribed dose. 


\section{DISCUSSION}

The goal of this study was to analyse the clinical response to high doses of CBZ in refractory epileptic patients. It is known that $75 \%$ of the patients will have at least half of their seizures controlled, while approximately $25 \%$ of them will not show significant improvement ${ }^{1,7,11,13,16,17}$. The number of seizure free patients tends to decline after 1 year, as seizures reccur after being controlled for a period $^{2.17}$.

CBZ is the drug of choice for epileptic patients with partial seizures followed or not by secondarily generalized tonic-clonic seizures ${ }^{18}$, as has been demonstrated by several studies that compared different antiepileptic drugs ${ }^{2,16,17}$. Monotherapy is the best regimen because it reduces antiepileptic drugs (AED) interactions and drug toxicity associated with polytherapy 6, 12, 13.22 . A second drug improves seizure's control in $11 \%$ of patients and increases drug toxicity in $90 \%{ }^{4}$. Aggressive monotherapy is the progressive increase of AED dose until seizure control is obtained or intolerable side effects are observed. The use of aggressive therapy without clinical improvement is considered a therapeutical failure ${ }^{4,10}$. Nevertheless, some authors consider therapeutic failures when seizures occur associated with AED plasma levels in the superior limit of therapeutical range ${ }^{9,22}$. However, there might be no correlation between clinical efficacy or side effects and AED plasma levels $\$ .14,15.20,24,25$. Aggressive monotherapy, on the other hand, raises the cost of the treatment and may expose patients to unpleasant side effects, or lead to an increase in seizure frequency without any other signs of drug intoxication, which is known as paradoxical effect. Another disadvantage may be the delay on defining therapeutical failures, so that patients that eventually would get some benefit with new drugs or surgical treatment would had been unnecessarily exposed for prolonged and potentially harmful effects of epileptic seizures in the brain.

Forty-eight patients who used a minimum dose of CBZ of $1200 \mathrm{mg} /$ day were analysed. Fifteen patients were on polytherapy with drugs that would potencially reduce the plasma level of $\mathrm{CBZ}^{13}$. $\mathrm{CBZ}$ was the only drug to have its dosage modified during the study.

The $\mathrm{CBZ}$ dose was progressively increased if no clinical improvement was observed and no side effects were noticed. However, an increased rate of remission with higher doses was not observed: only $19 \%$ of the patients showed seizure's control, while $81 \%$ had no significant reduction of the number of seizures. The patients that remained seizure-free used 1200 or $1400 \mathrm{mg} /$ day, and no improvement was observed with doses higher than $1400 \mathrm{mg} /$ day. Callaghan et al.$^{3}$, in a study with 25 patients, have not obtained any control with doses of CBZ higher than $16 \mathrm{mg} / \mathrm{kg} / \mathrm{day}$.

Former studies demostrated that long disease duration, high frequency of seizures 2 9. 22.24, presence of more than one type of seizure and complex partial seizures are factors of bad prognosis'. 5,7.9.21, 24. All patients analysed in this study had all these factors. The increase of the dose yielded more side effects such as diplopia, tremor, gastrointestinal symptoms and blurred vision, which were not tolerated by the patients and led to a reduction of the dose of CBZ. Potentially lifethreatening side effects ${ }^{1,16,19}$ were not observed.

Although the limit for drug dosage increase in most studies is considered the presence of side effects, we observed no benefit with doses of CBZ higher than $1400 \mathrm{mg} /$ day. Prospective studies may help to further define a therapeutic limit that would lead to actual benefits to patients using each one of the AED.

\section{REFERENCES}

1. Cabrini GP, Sironi VA, Marossero F, Baruzzi A. Indications of anticonvulsant plasma levels monitoring in medical and surgical treatment of epilepsy. J Neurosurg Sci 1979; 23:29-36.

2. Callaghan N, Kenny RA, O'Neill B, Crowley M, Goggin T. A prospective study between carbamazepine, phenytoin and sodium valproate as monotherapy in previously untreated and recently diagnosed patients with epilepsy. J Neurol Neurosurg Psychiatry 1985; 48:639-644. 
3. Callaghan N, O'Callaghan M, Duggan B., Feely $M$. Carbamazepine as a single drug in the treatment of epilepsy. J Neurol Neurosurg Psychiatry 1978; 41:907-912.

4. Cascino GD. Epilepsy: contemporary perspectives on evaluation and treatment. Mayo Clin Proc 1994; 69:1199-1211.

5. Chadwick D, Turnbill DM. The comparative efficacy of antiepileptic drugs for partial and tonic-clonic seizures. J Neurol Neurosurg Psychiatry 1985; 48:1073-1077.

6. Cornaggia CM, Cattabeni G, Cerisola N, Leozappa C, Mascetti PL, Massioni R, Porro G, Manghi E. Intractable epilepsies: an open trial with clobazam. Acta Neurol 1989; 11:1-9.

7. Defazio G, Lepore V, Specchio LM, Pisani F, Livrea P. The infuence of eletroencephalographic focus laterality on efficacy of carbamazepine in complex partial and secondarily generalized tonic-clonic seizures. Epilepsia $1991 ; 32: 706-711$.

8. Dooley JM, Camfield PR, Camfield CS, Gordon KE, Fraser AD. The use of antiepileptic drug levels in children: a survey of canadian pediatric neurologists. Can J Neurol Sci 1993; 20:217-221.

9. Elwes RDC, Jonhson AL, Shorvon SD, Reynolds EH. The prognosis for seizure in newly diagnosed epilepsy. N Engl J Med 1984; 311:944-947.

10. Gilman JT, Duchowny M, Jayakar P, Resnick TJ. Medical intractability in children evaluated for epilepsy surgery. Neurology 1994; 44:1341-1343.

11. Guerreiro CAM, Ramos MC, Annes M. Dosagens séricas repetidas de anticonvulsivantes em pacientes epilepticas. Arq Neuropsiquiatr 1993; 51:36-40.

12. Heller AJ, Chesterman P, Elwes RDC, Reynolds EH, Crawford P, Chadwick D, Johnson AL. Monotherapy for newly diagnosed adult epilepsy: comparative trial and prognostic evaluation. Epilepsia 1989; 30: 648 .

13. Jain KK. Investigation and management of loss of efficacy of an antiepileptic medication using carbamazepine as an example. J R Soc Med 1993; 86:133-136.

14. Kutt H, Penry K. Usefulness of blood levels of antiepileptic drugs. Arch Neurol 1974; 31:283-288.

15. Larkin JG, Herrick AL, McGuire GM, Percy-Robb IW, Brodie MJ. Antiepileptic drug monitoring at the epilepsy clinic: a prospective evaluation. Epilepsia 1991; 32:89-95.

16. Mattson RH, Cramer JA, Collins JF . A comparison of valproate with carbamazepine for the treatment of complex partial seizures and secondarily generalized tonic-clonic seizures in adults. N Engl J Med 1992; 327:765-771.

17. Mattson RH, Cramer JA, Collins JF. Comparison of carbamazepine, phenobarbital, phenytoin, and primidone in partial and secondarily generalized tonic-clonic seizures. N Engl J Med 1985; 313:145-151.

18. Neufeld MY. Exacerbation of focal seizures due to carbamazepine treatment in an adult patient. Clin Neuropharmacol 1993; 16:359-361.

19. Pellock JM, Willmore LJ. A rational guide to routine blood monitoring in patients receiving antiepileptic drugs. Neurology 1991; 41:961-964.

20. Pryse-Phillips W, Jardine F, Bursey F. Compliance with drug therapy by epileptic patients. Epilepsia 1982; 23:269-274.

21. Rodin EA. Medical and social prognosis in epilepsy. Epilepsia 1972;13:121-131.

22. Shorvon SD, Chadwick D, Galbraith AW, Reynolds EH. One drug for epilepsy. Br Med J 1978; 1:474-476.

23. Sillanpäa M. Carbamazepine: pharmacology and clinical uses. Acta Neurol Scand 1981; 64:69-76.

24. Strandjord RE, Johannessen SI. Single-drug therapy with carbamazepine in patients with epilepsy: serum levels and clinical effect. Epilepsia 1980; 21:655-662.

25. Van der Kleijn E, Schobben F, Termond E, Jansen W, Vree TB. Continuous monitoring of plasma antiepileptic drug levels. Acta Neurol Scand 1983; Suppl 97:91-114. 